\title{
A CASE STUDY: PARENTS' PERCEPTIONS ON CHILDREN BILINGUAL EDUCATION IN BALI
}

\author{
Pande Gede Artha Pratama \\ Postgraduate Program \\ Universitas Pendidikan Ganesha, Singaraja, Bali-Indonesia \\ Jalan Jend. A. Yani 67 Singaraja 81116, Telp. 0362-21541, Fax. 0362-27561 \\ E-mail: pande.pratama96@gmail.com
}

\begin{abstract}
ABSTRAK
Artikel ini membahas tentang persepsi orang tua tentang pendidikan bilingual pada anak-anak di Bali. Pendidikan bilingual dapat didefinisikan sebagai penggunaan dua bahasa dalam sistem pendidikan, di mana salah satu bahasa yang digunakan adalah bahasa Inggris dan dalam menggunakan kedua bahasa tersebut tanpa menyebutkan tingkat proporsi masing-masing bahasa. Investigasi kecil ini menggali informasi tentang seorang anak perempuan dari Bali yang menjadi bilingual dalam menggunakan bahasa Inggris dan Bahasa Indonesia dan persepsi orang tuanya tentang pendidikan bilingual. Investigasi ini melibatkan observasi terhadap partisipan, penyebaran kuesioner dan wawancara dengan orang tuanya. Hasil penelitian menunjukkan bahwa orang tua ingin anak-anak mereka menjadi bilingual karena itu akan membantunya untuk mendapatkan kehidupan yang lebih baik. Selain itu, kolaborasi antara guru, orang tua, masyarakat dan lingkungan diperlukan untuk mempromosikan pendidikan bilingual tanpa harus kehilangan bahasa ibu dari anak-anak, karena orang tua percaya bahwa menjadi bilingual berarti anak-anak dapat berbicara bahasa asing dan bahasa ibu secara seimbang dalam situasi dimana penggunaan Bahasa tersebut diperlukan.
\end{abstract}

Kata Kunci: pendidikan bilingual, persepsi orang tua

\begin{abstract}
This article aimed to discuss the parents'perceptions, on children bilingual education in Bali. Bilingual education could be defined as involving or using two languages in education system, in which one of the language used is students' native language and in using the languages without mentioning the degree of each language proportion. This small investigation explored a young Balinese girl who became bilingual in English and Bahasa Indonesia and her parents' perceptions about bilingual education. It involved participant observation, questionnaires administer and interview with her parents. The results of the study showed that the parents wanted their children to be bilingual because it would help in getting better life. Besides, collaboration between teachers, parents, society and environment is needed in order to promote bilingual education without losing children native language, because the parents believe that being bilingual meant children can speak both foreign language and native language equally without losing their native language.
\end{abstract}

Keywords: Bilingual Education, Parents'Perceptions

\section{INTRODUCTION}

In the context of Bali, bilingual education may be attributed to be a reflection of numerous factors such as the linguistic heterogeneity in a country or region (for example: Bahasa Indonesia, local/Balinese language and English), specific social or religious attitudes (for example: Sanskrit for Hinduism, Balinese language for Balinese social life); or the desire to promote national identity (Bahasa Indonesia for foreign speakers). In addition, innovative language education programs are often implemented to promote proficiency 
in international language of wider communication, together with proficiency in national and regional language. The use of different language in learning process would affect student' skills in using more than one language.

Bilingualism is often defined in the context when an individual is able to utilize at least two languages. Bloomfield in Artini \& Nitiasih (2014) defines bilingualism as a "native-like control of two languages". By contrast, Haugen in Fauziati (2014) states that bilingualism begins when the speaker of one language can produce complete meaningful utterances in the other language. If a person speaks two languages, it is beneficial for them both socially and for their brain development.

Nowadays, there are some schools that offer bilingual education program. They teach the students bilingually, which means that the students do not only learn about the language but also learn the material in two languages. Bilingual schools are available from kinder garden to senior high school level. It was because bilingual becoming a new demand by people as a path way to success. Basically, bilingual schools use English in the learning process and also the use their national language in daily conversation in the classroom.

Sending children to a blilingual school is becoming a trend in Bali. This is probably to do with the development of tourism industry in Bali. English becomes an asset for employment opportunities in Bali. Many parents consider that by entering a bilingual school their children's ability in speaking two languages would increase. This study focuses on the parents' perceptions for bilingual children in a bilingual school that promotes early bilingual childhood development. The subject was a 5 year old girl who went to a bilingual school in Singaraja. Her parents were well-educated since her mother was graduated from a post graduate program of English language education and her father was graduated from bachelor program of English language education.

\section{Bilingual and Bilingual Education}

Bialystok (2004) as citied at Mahsain (2014) found that bilinguals score the same as monolinguals in non-verbal tests, but less than monolinguals in verbal tests. Bialystok's study, however, claims that they have not found strong scientific evidence in their favour. In the context of bilingual education in Bali, bilingualism can be straight forwardly described as a concept of teaching that use two languages as the medium of instruction, one of those is an international or prestigious language (i.e. English). However, in the context of educational research in general, the term tends to be very complicated to define as it involves different language situations in different regions and countries (Chen, 2017). According to its literal meaning, "bilingual education" usually refers to any educational program that involves two languages in the progress of teaching. Chen also stated that bilingual education has developed for a long time, and many statements on its definition are concluded by some worldwide famous scholars like Anderson and Boyer (1970). But here is a definition that is more relevant to the primary school education, which is represented as "any system of school education in which, at a given moment in time and for a varying amount of time, simultaneously or consecutively, instruction is planned and given in at least two languages" (Hamer \& Blanc citied in Chen, 2017). This definition stresses the use of two languages as media of instruction rather than achieving academic purposes through two languages. As Baker (2001) claimed that, the term of "bilingual education" is like "a simple label for a complex phenomenon". Although many theorists define bilingual education from different angles, most of them share common ground in the following three aspects: school is usually the context of bilingual education; two languages are involved as teaching languages; one of the two languages should be students' first/national language, and the other one is students' second language or can be international language.

Baker (2001) state that the term bilingual education is not as straightforward as it sounds. Mackey (1970) as cited in Baker (2001) classified bilingual education includes 90 varieties of bilingual education. Ferguson, Houghton \& Wells, (1977), as cited in Baker, 
(2001) provided several purposes of bilingual education with varying and conflicting philosophies. Some emphasize monolingual forms of education and they are assimilative in nature but some others are pluralist and additive in nature allowing participants to use (Baker, 2001). In other hands, United Nations Educational, Scientific and Cultural Organization (UNESCO) (1990) embraces the term bilingual education to refer to describing an education environment in which national, native and international languages are spoken (Eteke, 2017). UNESCO states that bilingual education is the education system of using two different instructional languages, one of which is not the learner's first language". Bilingual education differs from conventional language education programmes prepared for EFL and ESL learners. It encompasses receiving education or instruction in two languages instead of only learning the languages themselves as different subjects. It also requires the non-native language exposure in specific contents, which makes it a means of teaching and learning. It gathers learners and teachers from diverse linguistic, cultural and national backgrounds together and ensures conformity among them under a lingua franca (Baker, 2001). Recently, Cambridge Education Brief 3 (2015) as stated in Eteke (2017) defined bilingual education as the use of two or more languages as medium of instruction for content subjects.

Thus, in general, bilingual education could be defined as involving or using two languages in education system, in which one of the language used is students' native language and in using the languages without mention the degree of each language proportion. However, Chen (2017) stated that since there is no one certain definition can be accepted by all people, the criteria of effective bilingual education should be kept in every individual's mind with everyone's own judgement.

\section{Helping Children Become Bilingualism}

Parents can help children become bilingual in several ways (Artini and Nitiasih, 2014):

a) Use two languages from the beginning. It can be started in conversation with the children. Let them know both languages because based on the results of research, there is no negative impact if a child is exposed in two languages earlier.

b) If one language is used exclusively at schools, use another language intensively at home. Thus, exposure remains in different languages in different situations or places.

c) Provide opportunities, media and learning resources both languages in daily life. For example prepare interesting story book in English and speak Bahasa Indonesian with the parents.

\section{Discussions on Types of Bilingual Educa- tion}

Chen (2017) stated based on different standards and factors such as teaching goals, teaching means, nature of teaching objects etc., there are many classifications for bilingual education. Mackey firstly classifies no less than 90 different types of bilingual education in terms of the languages of the home, the languages of the curriculum, the languages of the community in which the school is located, and the international and regional status of the languages (Mackey, citied in Chen, 2017), but it is too detailed to identify. Baker (2001) concludes that those classifications are not systematic and integral enough. He divides bilingual education into ten parts which can be collected into two categories: weak forms and strong forms. The weak forms mainly aim at assimilating the minority languages rather than maintain them, including submersion, submersion with withdrawal classes, segregationist, transitional, mainstream with foreign language teaching, and separatist (Baker, 2001). On the other hand, the strong forms intend to develop both of the two languages that in use: immersion, maintenance or heritage language, two-way or dual language, and mainstream bilingual (Baker, 2001). Weak forms contain bilingual children but bilingualism is not fostered in school, and strong forms have bilingualism as an intended outcome.

\section{The Effect of Bilingual Education}


Cummins (2003) as citied at Eteke (2017) stated that bilingualism has positive effects on children's linguistic and educational development. In addition, it increases mental flexibility, inter-cultural skills and opportunities for global exchange and trade. Besides, bilingual education, also, boosts cognitive flexibility, and a growing number of studies report that life-long bilinguals outperform monolinguals on a number of non-linguistic tests of cognitive control. The importance of bilingual education is not limited to development of cognitive skills.

Chin (2015) citied in Eteke (2017) also assert that once the balance between native and second language is maintained, the language proficiency in second language and skills in native language tend to improve more, which leads not only to linguistic but also to an academic success as well. As Rivera (2002) citied in Eteke (2017) suggested a review of the research finds that bilingual education is effective in both English and content area knowledge (Eteke, 2017).

Bialystok (2010) as citied in Brickman (2017) found that there are multiple elements affecting early language development in preschool children including neurophysiologic factors, early language sequences, and emotional and environmental factors. The environments in which a child learns language is also important. Duursma (2007) in Brickman (2017) had examined the role of language environments and home literacy activities on bilingual's vocabulary development. They found that examining environmental supports for literacy activities, including determining the number of books found in the household, were factors related to use of the languages in the home (Brickman, 2017).

Brickman (2017) stated that learning is may provide important results regarding when the best period for dual language learning is. In her study, language input is referred to as significant language the child receives from the individuals they interact with. This includes input from the child's peers, teachers, siblings, family members, and caretakers. Language exposure from multiple sources is also noted in this study including television, radio, and other technologies. She also defined significant language input as when someone was speaking directly to the child or the child reacted to something spoken around them. Due to her data being auditory and not visual, it was difficult to differentiate when the child was actually being spoken to and when someone was speaking in the proximity around the child. Therefore, individual interpretations regarding this issue were left to the individual coders.

\section{METHODS}

This small investigation explored the ways in which a five-year young Balinese girl living in Singaraja, Northern part of Bali became bilingual in English and Bahasa Indonesia. She took kindergarden level in Aura Sukma Insani Bilingual School. In order to collect the data, this study involved participant observation, video recording on the interaction between the mother and the girl in their home, giving questionnaires proposed by Barker (2001) and interviewing her parents. This paper explored the parents' perceptions and rational for promoting bilingualism to her daughter. In order to collect the data, Baker (1992) as citied in Barker (2001) presented language background or functional bilingualism scale, which endeavour to measure actual use of two language as opposed to proficiency (see: Appendix 1). Besides, there were some questions guided the investigation, such as: a) what were the parents' perceptions about providing bilingualism for their daughter? b) What were the challenges they found in conducting bilingualism for her daughter?

The data were collected by using documentation method. A questionnaire was given to the parents and the response was analysed and described. To support the data, a semi-structured interview was conducted to the parents in order to cross-check the results of the questionnaires. And last, the video recording was conducted in order to gain more information about participant's bilingualism development in daily life contexts. 


\section{Background of the Family}

Since, this study belonged to a case study and as a mini investigation this study concerned on a family which conducted Bilingual Education for their first daughter. In this case, this family was selected because they had a commitment for educating their children bilingually. As the participant of this study, the background of participant's family was presented here. Ivy, 5 years old girl taking bilingual education at Aura Sukma Insani Bilingual School. Her parents were graduated from English Language Education Department at Universitas Pendidikan Ganesha, Singaraja Bali. Her parents are bilingual. Her mother worked as a lecturer at Institute for Tourism and Cruise Ship, and her father worked as a staff in the International Office and Partnership in one university in Singaraja. Ivy lived with her parents and they were fluent in English, Bahasa Indonesia and Balinese Language.

\section{FINDING AND DISCUSSION}

This section showed the findings from the questionnaires, the interviews and a transcript from a video recording when the participants retelling a short story from Bahasa Indonesia to English.

Table 1. Patterns of Language Interaction for the Participants

\begin{tabular}{|l|l|l|}
\hline $\begin{array}{l}\text { L a n g u ge e } \\
\text { used by } \\
\text { Participants }\end{array}$ & $\begin{array}{l}\text { Language } \\
\text { used to the } \\
\text { Participants }\end{array}$ & $\begin{array}{l}\text { L a n g u a e } \\
\text { used by the } \\
\text { activity }\end{array}$ \\
\hline $\begin{array}{l}\text { - She spoke } \\
\text { in bahasa } \\
\text { more often } \\
\text { than English } \\
\text { to her father. }\end{array}$ & $\begin{array}{l}\text { - Her father } \\
\text { used Bahasa } \\
\text { more often } \\
\text { than English } \\
\text { when he was } \\
\text { speaking to } \\
\text { the partici- } \\
\text { pant }\end{array}$ & $\begin{array}{l}\text { - She } \\
\text { watched TV } \\
\text { or video in } \\
\text { English more } \\
\text { often than } \\
\text { Bahasa }\end{array}$ \\
\hline
\end{tabular}

\begin{tabular}{|c|c|c|}
\hline $\begin{array}{l}\text { - She spoke } \\
\text { English } \\
\text { and Bahasa } \\
\text { equally to } \\
\text { her mother }\end{array}$ & $\begin{array}{l}\text { - Her mother } \\
\text { always speak } \\
\text { in English } \\
\text { and Bahasa } \\
\text { equally to the } \\
\text { participant }\end{array}$ & $\begin{array}{l}\text { - She some- } \\
\text { times lis- } \\
\text { tened to ra- } \\
\text { dio program } \\
\text { in English } \\
\text { more often } \\
\text { than English }\end{array}$ \\
\hline $\begin{array}{l}\text { - She spoke } \\
\text { in English } \\
\text { more often } \\
\text { than Ba- } \\
\text { hasa to her } \\
\text { friends in } \\
\text { the class- } \\
\text { room }\end{array}$ & $\begin{array}{l}\text { - Her friends } \\
\text { in the class- } \\
\text { room spoke in } \\
\text { English more } \\
\text { often than Ba- } \\
\text { hasa to her }\end{array}$ & $\begin{array}{l}\text { - She read } \\
\text { books in } \\
\text { English } \\
\text { and Bahasa } \\
\text { equally- She } \\
\text { did his reli- } \\
\text { gion using } \\
\text { bahasa more } \\
\text { often than } \\
\text { English }\end{array}$ \\
\hline $\begin{array}{l}\text { - She spoke } \\
\text { in English } \\
\text { more often } \\
\text { than Bahasa } \\
\text { to her teach- } \\
\text { ers }\end{array}$ & $\begin{array}{l}\text { - Her teacher } \\
\text { in bilingual } \\
\text { school spoke } \\
\text { in English } \\
\text { more often } \\
\text { than Bahasa } \\
\text { to her }\end{array}$ & $\begin{array}{l}\text { - She read } \\
\text { comics in } \\
\text { English more } \\
\text { often than } \\
\text { Bahasa }\end{array}$ \\
\hline $\begin{array}{l}\text { - She spoke } \\
\text { always in } \\
\text { Bahasa to } \\
\text { her neigh- } \\
\text { bour, friends } \\
\text { on the } \\
\text { playground, } \\
\text { grandpar- } \\
\text { ents and } \\
\text { other rela- } \\
\text { tives }\end{array}$ & $\begin{array}{l}\text { - Her neigh- } \\
\text { bour, friends } \\
\text { on the play- } \\
\text { ground, } \\
\text { grandpar- } \\
\text { ents and } \\
\text { other relatives } \\
\text { spoke always } \\
\text { in Bahasa to } \\
\text { her everyday }\end{array}$ & $\begin{array}{l}\text { - She listened } \\
\text { to music in } \\
\text { English more } \\
\text { often than } \\
\text { Bahasa } \\
\text { - Shop- } \\
\text { ping, play- } \\
\text { ing sports, } \\
\text { calling on } \\
\text { telephone, } \\
\text { doing social } \\
\text { activities and } \\
\text { other leisure } \\
\text { activities, she } \\
\text { used Bahasa } \\
\text { more often } \\
\text { than English }\end{array}$ \\
\hline
\end{tabular}

According to the table presented above, it could be seen that Ivy mostly got English in her daily conversation when she talked with her mother and also with her teachers and friends in the classroom. She watched TV program or video, read comics, 
listened music and radio program in English more often than Bahasa in order to required English experiences. It was supported by Duursma (2007) which stated the role of language environments and home literacy activities on bilingual's vocabulary development.

Language input is referred to as significant language the child receives from the individuals they interact with. This includes input from the child's peers, teachers, siblings, family members, and caretakers. Language exposure from multiple sources is also noted in this study including television, radio, and other technologies.

\section{Parents' Perceptions on Bilingual Education}

Ivy's parents agreed that it was very important for Ivy to enter bilingual education since early age. According to their own experiences, they had learnt English since they were 9 years old, but they could speak English well after they entered the university level (around 20 years old). With regard to their experience, they expected that their daughter could be bilingual since her daughter was still young. Ivy's mother also believed that being proficient in two languages or more would help to make a better life. Her belief were supported Cambridge Education which stated that bilingual increases "mental flexibility", "inter-cultural skills" and "opportunities for global exchange and trade". These reasons bring them to bring bilingual education for their daughter from early age. In other hands, they wanted her daughter had a good personal character because by learning the language, she could learn about the culture also.

Ivy's interest with English started when she was 2 years old. She liked watching English video and sometimes she repeated some English words following the model in the video. Besides, he spent a lot of time watching cartoons, and she repeated everything that was said in the movie or video. Moreover, after entering the school Ivy's parents put her in Bilingual School in Singaraja and she enjoyed being in that school. She could learn how to speak in English at school, and she spoke more at home with her parents.
Based on the table presented before, it could be seen that nobody spoke always in English to Ivy. According to Ivy's parents, they wanted her daughter could use English and Bahasa Indonesia equally. They wanted her daughter could speak in English well, and also maintained using Bahasa Indonesia and Balinese language as her first language. Besides, in every level of education it would be Bahasa Indonesia, English and Balinese language were taught at schools and also Bahasa and English would be used as Examination Subjects. Thus, they wanted Ivy become bilingual to help her in the next level of education. Ivy was in golden age of learning. Her parents believed that this is the best time to learn because in this age she could receive everything fast. It made Ivy's parents believed that there were no difficulties for Ivy to learn two languages. Besides, her school employed the well - established curriculum for bilingual education for young children.

However, Ivy's parents stated that sometimes they were worried about Ivy's bilingual education because there were some challenges and obstacles found by her parents. They thought that lack of support from community and family would affect Ivy's bilingualism. In her daily life, the majority of the population spoke Bahasa Indonesia and Balinese Language and also Ivy's close relatives always used bahasa Indonesia in their daily speaking at home. Ivy's parents assumed that in getting enough input about Bahasa Indonesia and Balinese language were easy. However in getting English input, Ivy only got it from the school (8 a.m. - 11 a.m. only), besides in daily interaction to her parents sometimes Ivy also used Bahasa Indonesia. Regarding to this obstacles, Ivy's parents prepared movie, video, comics and books in English to create more awareness about using English for Ivy. English is considered as the international language of business, technology, and science. It is the language that you need to succeed in the world. Therefore, it is not surprising that Ivy's parents wanted her daughter became fluent in English besides in bahasa Indonesia and Balinese language. Seeing the obstacles and challenges in 
Ivy's bilingual education, her parents expected that they need collaboration between parents and educators in the context of community. Parents and early child-hood teachers alike need to be educated on issues of bilingualism, including: the complex and lengthy process involved in bilingual language development in early childhood; the positive impact of productive bilingualism in the academic success of students, amply documented in the literature. A better understanding of both the advantages of maintaining the first language and the difficulties in reaching bilingualism should be given more attention, to use other resources in addition to speaking English at home and society would help student's ability in using English.

Educators and parents can support the use of different languages in the school by pushing for programs that aim at promoting bilingualism for children. When this is not possible, the schools should display a positive attitude toward the choices of language used by acknowledging, accepting, respecting, and promoting not only English but their native language and then students' local language, in this case Balinese language as well, because when the balance between native and second language is maintained, the language proficiency in second language and skills in native language tend to improve more (Chin, citied in Eteke, 2017). This can be accomplished by using approaches to teaching and learning in the classroom that capitalize on the language and culture of all the children, by teachers encouraging parents and other family members to speak both languages at home, by hiring personnel that are bilingual, by encouraging all personnel in the schools who are proficient in both languages to speak it in school for other purposes, and by providing parents with information regarding afterschool programs that promote both languages in the community.

\section{CONCLUSION}

Collaboration between parents and institutions of education is also needed to promote bilingual education for children. In addition, parents at home and educators in the classroom can teach young children lullabies, songs, poems, stories, dances, and games in different languages (English, Bahasa Indonesia and Balinese language); they can also use tools especially appealing to children such as the Internet, music, videogames, audiotapes, and TV programs in those language. As Brickman (2017) stated that significant language input as when someone was speaking directly to the child or the child reacted to something spoken around them. In this case, parents' perceptions about bilingual education was very important for the children because it would help to make a better life, generating good personal character because by learning the language, children could learn about the culture also. However, it was necessary for the children to learn about their native language (Bahasa Indonesia and Balinese language) to maintain their native language. Also, the support of families, environment and society would affect the success of being bilingual for the children because they support the system of school education in which the instruction is planned and given in at least two languages simultaneously or consecutively.

\section{REFERENCES}

Artini, L. P. \& Nitiasih, P. K. 2014. Bilingualism dan Pendidikan Bilingual. Graha Ilmu: Yogyakarta

Baker, Colin. 2001. Foundation of bilingual education and bilingualism. Great Britain: Biddles Ltd.

Brickman, Angela Kathryn. 2017. Parent Report And Audio Recording Patterns In Bilingual Children Who Speak A Minority Language At Home (Under graduate Honors Theses 1300). University of Colorado Boulder. (Retrieved from: https://scholar.colorado. edu/honr_theses/1300)

Chen, Yang. 2017. Evaluation Of Different Bilingual Education Models And Its Application On Primary School Children Literacy. Studies in English Language Teaching Volume 5 No. 4 Year 2017. ISSN 23729740 Retrieved from:(http://www. scholink.org/ojs/index.php/selt/article/ 
viewFile/1138/1269)

Eteke, Ceren. 2017. Language learning strategies in bilingual context: a case study. Ihsan Dogramaci Bilkent University: Curriculum and Instruction. Retrieved from: (http://repository.bilkent.edu.tr/bitstream/ handle/11693/33199/10149888. pdf? sequence $=1$ )

Fauziati, Endang. 2008. Mixed Speech of An Early Bilingual Child: A Case Study on Java nese-Indonesian Bilingualism. Kajian Linguistik dan Sastra, Vol 20 No. 2 Year 2008. Retrieved from: www.researchgate. net/publication/228591425

Firpo, Elena. 2016. Blended Learning and Bilingual Education. Research on Education and Media. Volume 8 No 1 Year 2016. Retrieved from: (https://www.research gate.net/publication/308394536_Blend ed_learning_and_bilingual_education)

Mahsain, Fatemah HMHA. 2014. Motivation Behind Code-Switching Among Kuwaiti Bilingual School's Students. University of Manchester: School of Arts, Language and Culture Retrieved from: (https://www. research.manchester.ac.uk/portal/ files/54563783/FULL_TEXT.PDF)

Rodriguez, M. Victoria. 2015. Families and Educators Supporting Bilingualism in Early Childhood. School Community Journal Volume 25 Nomor 2. Retrieved from: (http://www.schoolcommunitynetwork. org/SCJ.aspx) 